\title{
THERMODYNAMICS ANALYSIS OF HEAT PUMP ASSISTED CRYSTALLIZATION PROCESS
}

\author{
Adnan Al-Harahsheh ${ }^{1}$, Zaid Ahmed Al-Anber ${ }^{2}$, Omer Alnhoud ${ }^{3}$ \\ ${ }^{1}$ Dept. of Chemical Eng, Faculty of Eng., Mutah University, Karak,Jordan \\ ${ }^{2}$ Dept. of Chemical Eng., Faculty of Eng. Technology, Al Balqa'Applied University, Amman, Jordan. \\ ${ }^{3}$ Dept. of Civil Eng., Faculty of Eng., Al al-Bayt University, Al-Mafraq, Jordan \\ Email:z_alanber@bau.edu.jo
}

\begin{abstract}
In this work, the theoretical calculations were carried out for a heat pump assisted crystallization process. The studied method includes a heating process of mother liquor in a crystallizer for direct evaporative crystallization. R-134a is used as refrigerant. The coefficient of performance (COP), exergetic efficiency $\left(\eta_{e x}\right)$, and total irreversibility rate were calculated. It was also found that the highest irreversibility value was at condenser temperature of $25^{\circ} \mathrm{C}$ and evaporative temperature of $-15^{\circ} \mathrm{C}$. It was also found that the salt concentration in a slurry solution $\left(\mathrm{X}_{\mathrm{D}}\right)$ inside a crystallizer increases as $\mathrm{COP}$ increases.
\end{abstract}

Keywords: Heat pump, Crystallization Process, Refrigerant, Salt Concentration, Exergetic Efficiency.

\section{INTRODUCTION}

Crystallization is a solid liquid separation process in which mass transfer of a solute occurs from the liquid solution to a pure solid crystalline phase (process where solid particles are formed from a homogeneous phase) [1]. Crystallizers can be conveniently classified in terms of the method used to obtain deposition of particles: by cooling a concentrated hot solution; by evaporating a solution; or by adiabatic evaporation cooling [2-5]. The utilization of heat pumps in various chemical processes is considered as one of the promising methods for energy saving. To our knowledge, the utilization of heat pump in a crystallizer has not been deeply reported yet for the purpose of energy saving [6-11]. The heat pumps are investigated in many chemical processes such as air conditioning, distillation, absorption, desorption and water desalination [12]. Reasonable saving was obtained by introducing a heat pump in distillation and water desalination [13-15]. Other types of chemical heat pumps are intensively investigated and the economic analyses of the use of such type of heat pumps were reported [16-18]. One of the prospective uses of heat pumps in chemical processes is in separation processes of organic and inorganic compound from their mixture by using different crystallization methods such as counter current crystallization, direct contact and indirect contact evaporative crystallization [811]. For example, in a counter-current 
crystallizer there are two different zones: cooling and melting zones. In the cooling zone, heat is removed from the system in order to initiate the nucleation and crystal growth, while in melting zone heat is added to melt the formed crystal phase to the final required temperature. To carry out such process, two different sources of energy should be used; the cooling agent in cooling zone and steam or electrical heating in heating zone. This work presents a thermodynamics and energy analysis to serve the technical feasibility and the potential use of heat pump in the process of direct contact evaporative crystallization.

\section{SYSTEM DESCRIPTION}

Figure 1 shows a flow diagram of direct contact evaporative crystallization process using hot air as contact phase with solution. The process is carried out in a bubble column crystallizer. Air is heated usually by electrical heater or by contacting with other heating agents. Hot air of a flow rate (L) is brought into contact with solution (F) with a temperature and concentration $\mathrm{TF}, \mathrm{XF}$, respectively, in a bubble column causing the air to cool and some of liquid to evaporate. The air temperature will decrease from $\mathrm{T} 1$, at the column inlet, to $\mathrm{T} 2$ at the outlet. Consequently, the absolute and relative humidity will increase from $\alpha \mathrm{A} 1, \alpha \mathrm{R} 1$ to $\alpha \mathrm{A} 2$, $\alpha \mathrm{R} 2$, respectively. The enthalpy of air may remain constant if the contact in the bubble column is going under adiabatic conditions or it may change from $\mathrm{H} 1$ at the inlet to $\mathrm{H} 2$ at the outlet if other cooling conditions are applied. Distilled water of amount (W) is obtained by dehumidifying the air in a condenser (the evaporator of heat pump). Formed slurry concentrated solution (D) is separated to crystal phase $(\mathrm{K})$ and mother liquor $(\mathrm{M})$.

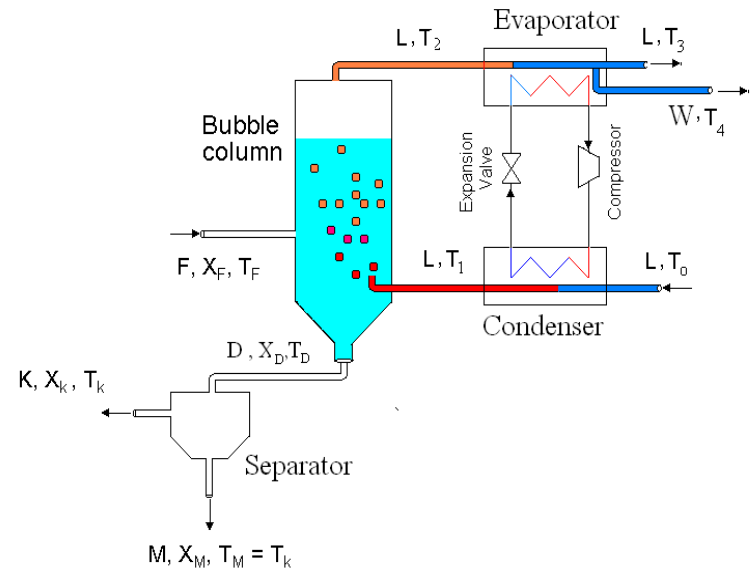

Fig.1. Principle scheme of direct contact evaporative crystallization process using hot air as contact phase with solution

The overall material balance is $[8,11]$ :

$$
F=K+M+L\left(\alpha_{A 1}-\alpha_{A 2}\right)
$$

The amount of evaporated solvent (water) is determined according to the difference of moisture content (air humidity) between the inlet and outlet as:

$$
W=L\left(\alpha_{A 1}-\alpha_{A 2}\right)
$$

Substituting Eq. (2) into Eq. (1):

$$
F=K+M+W
$$

Also from

$$
D=K+M
$$

Then Eq. 4 becomes

$$
F=D+W
$$

Balance on solute can be expressed as:

$$
F X_{F}=D X_{D}+W X_{W}
$$

where, $X_{F}, X_{D}, X_{W}$ are the salts concentrations in feed, slurry concentration solution and condensate phases, respectively. 
Taking into account that evaporated water contains zero amount of solute $(\mathrm{XW}=0)$ then equation 6 becomes:

$$
F X_{F}=D X_{D}
$$

An expression for the amount of crystal phase as slurry can be obtained by solving equation 7

$$
X_{D}=\frac{F X_{F}}{D}
$$

The amount of crystals formed can be calculated by knowing the efficiency of the separator. The amount of heat that must be added to the air is the same or less than amount of heat that must be delivered by heat pump in the condenser and can be calculated as [11]:

$$
Q_{H}=L\left(H_{1}-H_{o}\right)
$$

Evaporator energy balance is:

$$
Q_{L}=(L+W)\left(H_{3}-H_{2}\right)=(L+W) C_{p / a i r}\left(T_{3}-T_{2}\right)
$$

The measure of performance of a heat pump is expressed in terms of coefficient of performance COPHP, defined as

$$
C O P_{H P}=\frac{Q_{H}}{W_{i n}}
$$

By applying energy parlance on the heat pump

$$
W_{\text {in }}=Q_{H}-Q_{L}
$$

The second law of thermodynamics uses an energy balance for the analysis and the design of thermal systems. In the energy analyses of many systems, equation 13 can be used, [19]

$$
\text { Energy, } I=C_{p}\left[\left(T-T_{\infty}\right)-\left(T-T_{\infty}\right) \ln \left(T / T_{\infty}\right)\right]
$$

Where, the subscript $\infty$ denotes the reference conditions. The total energy is also given by equation 14 [20]

$$
I=I_{\text {Evap }}+I_{\text {Cond }}+I_{\text {Comp }}+I_{\text {valv }}+I_{\text {Crys }}
$$

Exergetic efficiency, $\eta_{e x}$, is calculated by equation 15 [21]

$$
\eta_{e x}=\frac{\left(1-\frac{T_{0}}{T_{E}}\right)}{C O P}
$$

\section{RESULTS AND DISCUSSION}

Variation of COP with evaporator temperature is presented in Figure 2. These values of COP are calculated using Eq. 8 to 10. The condenser temperatures are fixed constant at $25^{\circ} \mathrm{C}$ and $30^{\circ} \mathrm{C}$. We found that the highest $\mathrm{COP}$ of system is found at $5^{\circ} \mathrm{C}$ for evaporative temperature, $25^{\circ} \mathrm{C}$ condenser temperature and about 10 for COP.

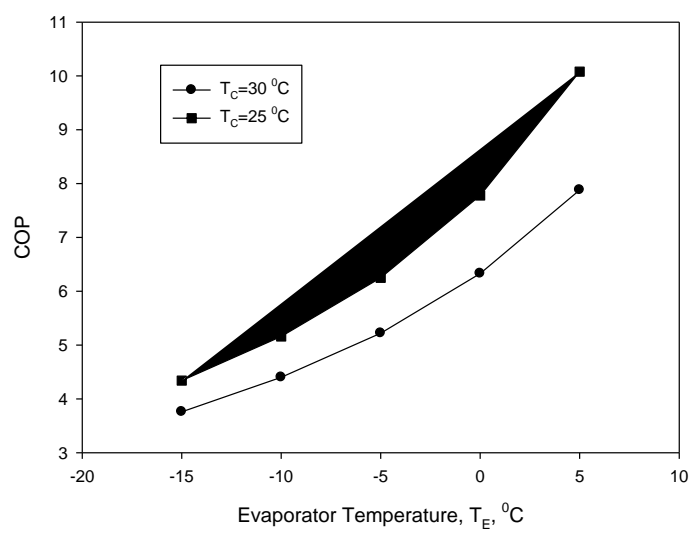

Fig.2. The coefficient of performance, COP versus the evaporator Temperature, TE.

Figure 3, shows the plot of COP versus the salt concentration in the slurry concentration solution. The condenser temperature is kept constant at $25^{\circ} \mathrm{C}$. 
The flow are of air enters to the condenser is $0.05 \mathrm{~kg} / \mathrm{s}$. The material balance (equations 1 to 8 ) is used to calculate the salt concentration in the slurry concentration solution as a function of COP. It is found that the values of COP increase in direct proportion to the increases of the salt concentration in the slurry concentration solution.

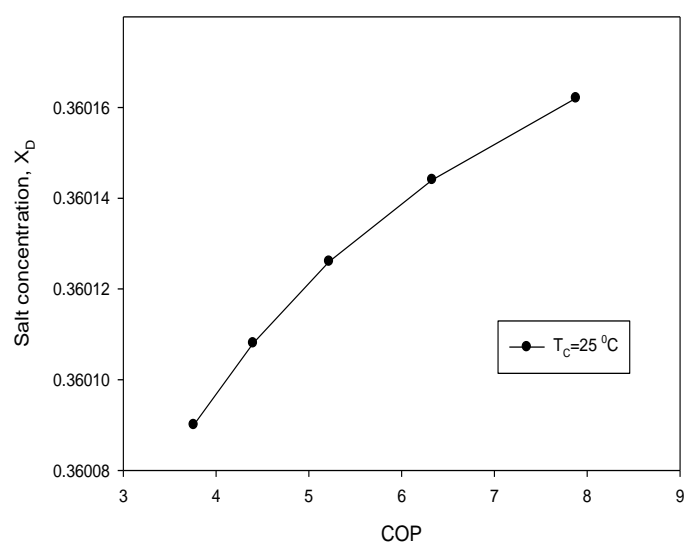

Fig.3. The coefficient of performance, COP versus the salt concentration, $\mathrm{XD}$

Figure 4 shows the total irreversibility values versus the evaporator temperature. Equations 13 and 14 are used to calculate the total irreversibility. The condenser temperature has been kept constant and the refrigerant R134a has also used in the system. It can be seen that the highest total irreversibility rate of system is found at $-15^{\circ} \mathrm{C}$ for evaporative temperature and about 1180 Watt for total irreversibility rate.

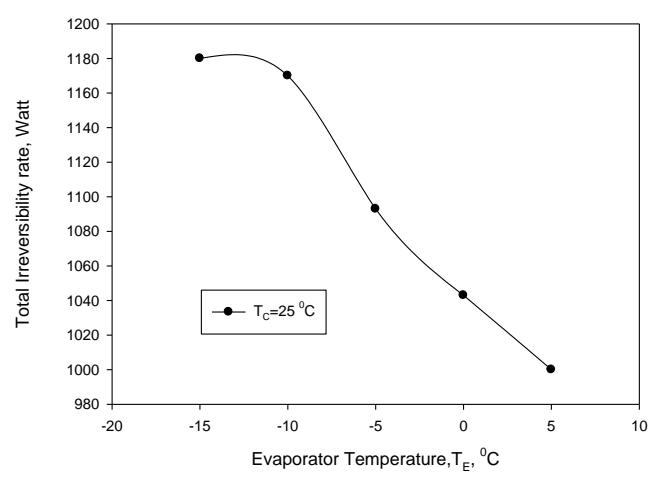

Fig. 4. The total irreversibility rate, I versus the evaporator Temperature, TE.
Exergy efficiencies versus the evaporative temperature are illustrated in Figure 5. The condenser temperature is set fixed at $25^{\circ} \mathrm{C}$. It was also found that as evaporator temperature increases, the exergy efficiency increases.

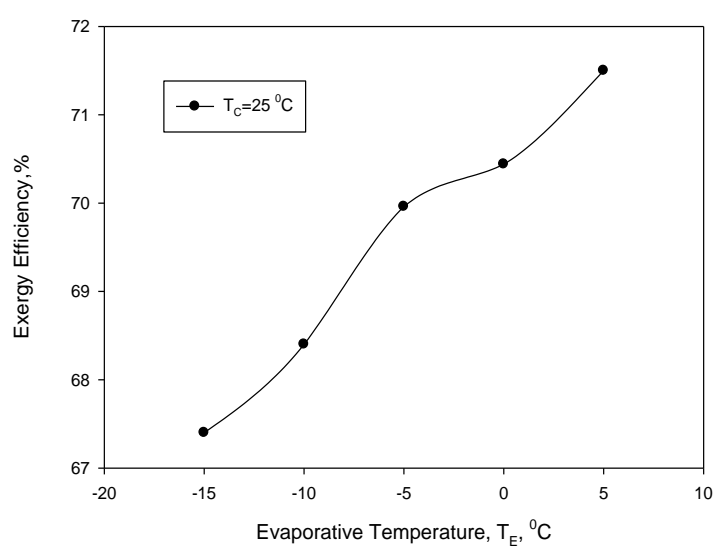

Fig. 5. The exergy efficiency versus the evaporator Temperature, $\mathrm{T}_{\mathrm{E}}$.

\section{CONCLUSIONS}

The thermodynamics and exergy analysis of the technical feasibility and the potential use of heat pump in the process of direct contact evaporative crystallization were studied. This studied design aims to reduce and save the consumption of heat. It was found that the values of the coefficient of performance, exergy efficiency, total irreversibility and the salt concentrations in slurry concentration solution depends on the condenser and evaporator temperatures.

\section{REFERENCES}

[1] Christie J. Geankoplis, Transport processes and unit Operations, 3rd Ed, United States of America, 1993.

[2] J. M. Coulson, J. F. Richardson, J. R. Backhurst, J. H. harker, Chemical Engineering, Volume Two, 3rd Ed, 1978.

[3] Mullin J.W., Crystallization, 3rd Ed., MPG Book, London, 2000.

[4] Perry, H. Robert, Green .W. Don, Perry's chemical engineer's hanbook, MC Graw Hill, New York, 1999. 
[5] Alan S. Foust, Leonard A.Wenzel, Curtis W.Clump, Louis maus ,L. Bryce Andersen, Principles of Unit Operations, Bethlehem, Pennsylvania 1960 .

[6] Camelia Stanciu, Adina Gheorghian, Dorin Stanciu, Alexandru Dobrovicescu, Exergy Analysis And Refrigerant Effect On The Operation And Performance Limits Of A One Stage Vapor Compression Refrigeration System. TERMOTEHNICA 1/2011.

[7] Daikin Industries, Ltd., Japanese Patent "AirCooled Absorption- Refrigerator”, 1998.

[8] Adnan M. Al-Harahsheh, Theoretical analyses of energy saving in a direct contact evaporative crystallization through the installation of heat pump, Desalination 251, (1-3) (2010), 47-52.

[9] Adnan M. Al-Harahsheh , A heat pump in a countercurrent crystallization process Applied Thermal Engineering, 25(4) (2005),545-555

[10] Adnan M. Al-Harahsheh, Theoretical Analyses of Energy Saving in Indirect Contact Evaporative Crystallization by Using Combined Cycle of Vapor Recompression Heat Pump and Throttling Valve. Jordan Journal of Mechanical and Industrial Engineering, 4(3), (2010), 358 - 363.

[11] Zaid Ahmed Al-Anber, Heat Saving in Evaporative Crystallization by Introducing a Heat Pump, Yanbu Journal of engineering and science, 6(2013)91-104.

[12] Bohdan Soroka, Laborelec, Application Note Industrial Heat Pumps. Available from www.leonardo-energy.org/node/1622, 2015.

[13] Eduardo Díez, Paul Langston, G Abriel Ovejero, M. Dolores Romero, Economic Feasibility of Heat Pumps In Distilition to Reduce Energy Use. Applied Thermal Engineering. 29(5), (2009), 1216-1223.
[14] Amiya K. Jana, Advances in heat pump assisted distillation column: A review. Energy Conversion and Management, 77,(2014), 287-297

[15] S. Gopichand, S. Devotta, P. J. Diggorv and F. A. Holland, Heat pump assisted distillation. VIII: Design of a system for separating ethanol and water, International Journal of Energy Research, 12, (1), (1988), 1-10

[16] Colak N, Hepbasli A. A review of heat-pump drying (HPD): Part 2 - Applications and performance assessments. Energy Convers Manage 50(9), (2009), 2187-99.

[17] Nagota T, Shimoda Y, Mizuno M. Verification of the energy-saving effect of the district heating and cooling system - simulation of an electricdriven heat pump system. Energy Buildings; 40(5), (2008), 732-41.

[18] Lazzarin R, Noro M. District heating and gas engine heat pump: economic analysis based on a case study. Appl Therm Eng 26 (2-3), (2006), 193-9.

[19] E. Bilgen, , H. Takahashi, Exergy analysis and experimental study of heat pump systems, Exergy, An International Journal, 2(4), (2002), 259-265.

[20] Wang Fang, Fan Xiao-Wei, Chen Jie, Lian Zhi, Energy and exergy analysis of heat pump using R744/R32 refrigerant mixture, Thermal Science.;18(5), (2014), 1649-1654

[21] Ibrahim Atmaca, Sezgi Kocak, Theoretical Energy And Exergy Analyses Of Solar Assisted Heat Pump Space Heating System, Thermal Science, 18, (2014), 417-427 


\section{تحليل الايناميكا الحرارية لمضخة الحرارة بمساعدة عملية التبلور}

$$
\begin{aligned}
& 1 \text { عدنان الحر اشي، } 2 \text { زايد أحمد العنبر ،3 عمير النهود }
\end{aligned}
$$

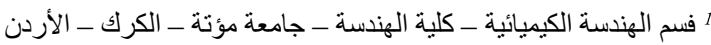

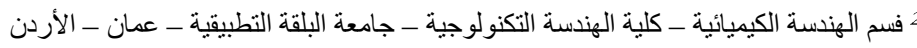

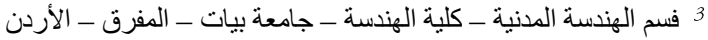

الملخص:

تناول هذا البحث الحسابات النظرية لمضخة الحرارة المساعدة لمبلور. وقد شملت الدراسة عملية نسخين المحلول الأم في و عاء التبلور لعمل تبلور تبخيري مباثر. تم إستخدم R-134 في نظام التبريد. وقد تم حساب كلاً من معامل الأداء (COP) و كفاءه Exergetic ومعدل الإنعكاسية الكلى للنظام، وقد وجد أن أعلى قيمة

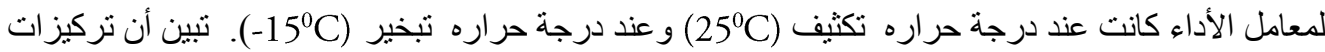
الملح في محلول المعلق (XD) داخل وعاء التبلور يزداد بإزدياد معامل الأداء. . 